\title{
Analysis of Farming Business Density, Area Density, and Economic Density of Beef Cattle to Supports Human Welfare in the Fulfillment of Animal Protein in 4.0 Industrial Revolution Era in Gorontalo District
}

\author{
Andi Yulyani Fadwiwati ${ }^{1, *}$, Surya ${ }^{1}$ \\ ${ }^{1}$ Agricultural Technology Research Center Gorontalo - Ministry of Agriculture, Gorontalo \\ *Corresponding author. Email: ayulyanifadwiwati@yahoo.co.id
}

\begin{abstract}
This study aims to analyze farming business density, area density and economic density of beef cattle to support human welfare in the fulfillment of animal protein in 4.0 industrial revolution era in Gorontalo District. This research uses a literature study and survey methods. The data obtained were then calculated for the analysis of farming business density, area density and economic density of beef cattle in Gorontalo District. The results of the analysis of farming business density obtained 15 Sub-Districts with rarely categories and 4 Sub-Districts with moderate categories. Then the area density is 15 Sub-Districts with a rarely category, 1 Sub-District with a moderate category, 2 Sub-Districts with a solid category, and 1 Sub-District with a very solid category. Furthermore, the economic density of livestock in all Sub-Districts in Gorontalo District is in rarely category. This illustrates that farming business density, area density and economic density still haves a great opportunity to be developed in Gorontalo District.
\end{abstract}

Keywords: Farming Business Density, Area Density, Economic Density.

\section{INTRODUCTION}

The livestock sector, especially beef cattle, as a meat producer for the fulfillment of community animal protein, is a very promising sector to be developed. This is due to increased demand related to food fulfillment [1] of high nutritional value, especially the need for animal protein, so that the production rate of beef cattle can increase in quantity and quality [2].

Gasification of beef cattle in its development has several variables, such as capital, land availability, feed and so on. Beef cattle can be integrated with food crops, so as to maximize local resources and regional program strategies [3], because the beef cattle business has a great opportunity to be developed [4].

Beef productivity can be seen from the recording of meat production [5]. In line with this, the productivity of the local beef cattle business becomes the main concern of the government because beef cattle are the main supporter of the availability of meat in Indonesia, even though the amount available domestically is still insufficient and cannot even keep up with the national demand for meat. This is supported by research results [6], that the availability of beef in Indonesia has decreased every year.

The development of beef cattle can be seen based on farming business density, area density, and economic density, so that it can be used as a basis for policy making in the beef cattle sector in Gorontalo District. The review of several studies is very significant in determining areas for livestock business locations such as carrying capacity and its relevance to urban and regional planning [7], the value of sustainability of beef cattle farming in a complex environmental system [8] including the prospect of 
beef cattle production [9], socio-culture of agricultural commodity production [10] as a source of animal feed so that the productivity of beef cattle can increase in relation to the fulfillment of meat supply for the community. In addition, geographical conditions, topography, human resources, feed, water, and government strategies, capital, level of knowledge, area, and management of beef cattle cultivation will certainly affect the profitability of the beef cattle business.

Broadly speaking, the production growth originating from beef cattle can be increased through a beef cattle development strategy based on farming business density, area density, and economic density, so as to realize integrated, harmonious and optimal beef cattle management.

Based on the explanation above, the writer intends to analyze farming business density, area density and economic density of beef cattle to support human welfare in the fulfillment of animal protein in 4.0 industrial revolution era in Gorontalo District.

\section{MATERIALS AND METHODS}

The research was carried out related to the analysis of farming business density, area density and economic density of beef cattle in 19 Sub-Districts in Gorontalo District from January to September 2020.

The research was conducted using descriptive methods accompanied by simple statistical analysis. The data collection methods are secondary data and primary data, namely area of harvest of food crops such as rice, corn, and soybeans which were carried out in 19 Sub-Districts in Gorontalo District. Then the data will be processed and analyzed in the form of parameters analysis of farming business density, area density and economic density of beef cattle [11] as follows:

\subsection{The Farming Business Density}

The farming business density is the number of beef cattle population per hectare of farm land, where:

$$
\text { The Farming Business Density }=\frac{\mathrm{a}}{\mathrm{b}}
$$

Information:

$\mathrm{a}=$ Total population of beef cattle (ST)

$\mathrm{b}=$ Farm area $(\mathrm{Ha})$ in each Sub-District of Gorontalo District
The criteria used were very solid $>2$, solid $>1-2$, moderate $0.25-1.0$, and rarely $<0.25$.

\subsection{The Area Density}

The area density is the density of ruminants per $\mathrm{km}^{2}$ for Gorontalo District:

The Area Density $=\frac{\mathrm{a}}{\mathrm{d}}$

Information:

$\mathrm{a}=$ Total population of beef cattle (ST)

$\mathrm{d}=$ Total area $\left(\mathrm{km}^{2}\right)$ in each Sub-District of Gorontalo District

The criteria used for area density are very solid $>$ 50 , solid $>20-50$, moderate $10-20$, and rarely < 10.

\subsection{The Economic Density}

The economic density of beef cattle can be measured based on the number of beef cattle population in 19 Sub-Districts of Gorontalo District in 1000 (ST) inhabitants:

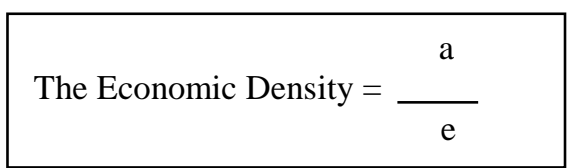

Information:

$\mathrm{a}=$ Total population of beef cattle (ST)

$\mathrm{e}=$ Total population in each Sub-District of Gorontalo District

The criteria used were very solid $(>300)$, solid (100 - 300), moderate $(50-100)$, and rarely $(<50)$.

\section{RESULT AND DISCUSSION}

\subsection{The Farming Business Density}

The farming business density in Gorontalo District can be seen in Table 1.

Table 1 above shows that farming business density in Gorontalo District only has two categories, namely the moderate category and rarely category. This shows that the number of livestock causes variations in farming business density. Overall farming business density category shows that the variation is not too different between each SubDistricts in Gorontalo District where farming business density is still below number one. The 
increase in beef cattle population can be increased through the development of land potential, human resources, feed, and feed models [12].

Table 1. The Farming Business Density in Gorontalo District

\begin{tabular}{lcc}
\hline Sub-District & $\begin{array}{c}\text { The Farming } \\
\text { Business Density }\end{array}$ & Category \\
\hline Asparaga & 0.10 & Rarely \\
Batudaa & 0.10 & Rarely \\
Batudaa Pantai & 0.14 & Rarely \\
Bilato & 0.12 & Rarely \\
Biluhu & 0.15 & Rarely \\
Boliyohuto & 0.27 & Moderate \\
Bongomeme & 0.10 & Rarely \\
Dungaliyo & 0.20 & Rarely \\
Limboto & 0.12 & Rarely \\
Limboto Barat & 0.16 & Rarely \\
Mootilango & 0.14 & Rarely \\
Pulabala & 0.06 & Rarely \\
Tabongo & 0.17 & Rarely \\
Telaga & 0.25 & Moderate \\
Telaga Biru & 0.22 & Rarely \\
Talaga Jaya & 0.53 & Moderate \\
Tibawa & 0.12 & Rarely \\
Tilango & 0.57 & Moderate \\
Tolangohula & 0.12 & Rarely \\
\hline Source: Processed data, 2020. &
\end{tabular}

The assessment of farming business density in 19 Sub-Districts in Gorontalo District shows that farming business density is still dominated by rarely category with an area of Gorontalo District of 2.125.47 $\mathrm{km}^{2}$ [13]. The strategy that can be done in using the diversity of natural resources is by increasing integrated farming [14].

\subsection{The Area Density}

The area density in the 19 Sub-Districts of Gorontalo District listed in Table 2. Table 2 shows that the area density for all Sub-Districts in Gorontalo District has four categories, namely very solid, solid, moderate, and rarely but still dominated by rarely categories. This shows that the average area in each Sub-Districts in Gorontalo District has a low number of Animal Units (AU) so that it does not really affect the density of area. This is in accordance with the opinion [15], that in order to identify an area it is necessary to use a systematic functional method approach and place all aspects that function and have a position in supporting the mission of livestock sector.

Table 2. The Area Density in Gorontalo District

\begin{tabular}{lcc}
\hline \multicolumn{1}{c}{ Sub-District } & $\begin{array}{c}\text { The Area } \\
\text { Density }\end{array}$ & Category \\
\hline Asparaga & 7.11 & Rarely \\
Batudaa & 2.74 & Rarely \\
Batudaa Pantai & 5.61 & Rarely \\
Bilato & 1.75 & Rarely \\
Biluhu & 2.75 & Rarely \\
Boliyohuto & 13.79 & Moderate \\
Bongomeme & 4.25 & Rarely \\
Dungaliyo & 2.13 & Rarely \\
Limboto & 8.09 & Rarely \\
Limboto Barat & 3.02 & Rarely \\
Mootilango & 4.80 & Rarely \\
Pulabala & 1.99 & Rarely \\
Tabongo & 4.08 & Rarely \\
Telaga & 2.61 & Rarely \\
Telaga Biru & 4.87 & Rarely \\
Talaga Jaya & 6.00 & Rarely \\
Tibawa & 7.93 & Rarely \\
Tilango & 28.32 & Solid \\
Tolangohula & 105.28 & Very Solid \\
\hline Source: Processed data, 2020. & & \\
\hline & &
\end{tabular}

The results of the calculation of area density in 19 Sub-Districts in Gorontalo District show that area density in this case the wide availability of land and potential of agricultural waste produced are very promising opportunities to be developed and utilized for development in livestock area, especially beef cattle in Gorontalo District. This is in accordance with the opinion of Mukson [16], that one of the factors that plays an important role in the development of beef cattle is $92.3 \%$ due to the land area, the adequacy of the available forage for beef cattle, labor, and available capital.

\subsection{The Economic Density}

The following is the economic density of livestock in Gorontalo District, which can be seen in Table 3. Based on Table 3 above, it is known that the economic density of all is in rarely category in 19 Sub-Districts of Gorontalo District. The economic density description also informs that the population and population of beef cattle in each Sun-Districts are 
different. Efforts to develop animal husbandry which are important to support the increase in people's income in this area should be directed at SubDistricts that have low levels of economic and

Table 3. The Economic Density in Gorontalo District

\begin{tabular}{lcl}
\hline Sub-District & $\begin{array}{c}\text { The } \\
\text { Economic } \\
\text { Density }\end{array}$ & Category \\
\hline Asparaga & 17.68 & Rarely \\
Batudaa & 14.76 & Rarely \\
Batudaa Pantai & 3.65 & Rarely \\
Bilato & 16.26 & Rarely \\
Biluhu & 6.93 & Rarely \\
Boliyohuto & 27.82 & Rarely \\
Bongomeme & 14.70 & Rarely \\
Dungaliyo & 42.46 & Rarely \\
Limboto & 26.06 & Rarely \\
Limboto Barat & 74.14 & Rarely \\
Mootilango & 42.02 & Rarely \\
Pulabala & 43.64 & Rarely \\
Tabongo & 26.57 & Rarely \\
Telaga & 20.07 & Rarely \\
Telaga Biru & 30.94 & Rarely \\
Talaga Jaya & 9.68 & Rarely \\
Tibawa & 28.39 & Rarely \\
Tilango & 16.61 & Rarely \\
Tolangohula & 26.73 & Rarely \\
\hline Soure: Processed & &
\end{tabular}

Source: Processed data, 2020.

technical density [17]. The number of beef cattle population that is different for each Sub-Districts shows that there are still obstacles faced by breeders, one of which is capital. The decline in beef cattle maintenance can be influenced by many factors, such as low capital and the lack of farmer's ability to organize his beef cattle business [18]. Furthermore, suggest that the carrying capacity of a beef cattle business can be caused by land resources and plant products whose waste can be used as an alternative to animal feed [19].

\section{CONCLUSION}

The results obtained indicate that the analysis of farming business density obtained 15 Sub-Districts with rarely categories and 4 Sub-Districts with moderate categories. Then the area density is 15 SubDistricts with a rarely category, 1 Sub-District with a moderate category, 2 Sub-Districts with a solid category, and 1 Sub-District with a very solid category. Furthermore, the economic density of livestock in all Sub-Districts in Gorontalo District is in rarely category. This illustrates that farming business density, area density and economic density still haves a great opportunity to be developed in Gorontalo District.

\section{REFERENCES}

[1] N. Anggraini, R.A. Putra, Analisis Potensi Wilayah dalam Pengembangan Peternakan Sapi Potong di Kecamatan Sijunjung Kabupaten Sijunjung, Jurnal AGRIFO 2(2) (2017) 82-100. [In Bahasa Indonesia]

[2] K.I. Adinata, Sunarso, W. Sumekar, Potensi Komoditas Ternak Sapi Potong dan Daya Dukung Limbah Tanaman Padi di Kabupaten Sukoharjo, Buana Sains 16(2) (2016) 111-120. [In Bahasa Indonesia]

[3] P.R. Matitaputty, B. Kuntoro, Potensi dan Strategi Pengembangan Kawasan Peternakan Ruminansia dan Pemanfaatan Limbah Tanaman Pangan di Kabupaten Maluku Tenggara Barat (MTB), Jurnal Peternakan 7(2) (2010) 70-81. DOI: http://dx.doi.org/10.24014/jupet.v7i2.461. [In Bahasa Indonesia]

[4] Y. Ihza, Pengaruh Harga Daging Sapi Internasional, Kurs, dan GDP Per Kapita terhadap Impor Daging Sapi di Indonesia, Economics Development Analysis Journal 6(3) (2017) 328-345. DOI: https://doi.org/10.15294/edaj.v6i3.22282. [In Bahasa Indonesia]

[5] C. Wasike, T.M. Magothe, A.K. Kahi, K.J. Peters, Factors that influence the efficiency of beef and dairy cattle recording system in Kenya: A SWOT-AHP analysis, Tropical Animal Health and Production 43(1) (2011) 141-152. DOI: https://doi.org/10.1007/s11250-010-9666$\underline{3}$

[6] S. Rusdiana, Fenomena Kebutuhan Pangan Asal Daging Dapat Dipenuhi Melalui Peningkatan Usaha Sapi Potong di Petani, Jurnal SosialEkonomi Pertanian dan Agribisnis (SOCA) 13(1) (2019) 61-83. DOI: https://doi.org/10.24843/SOCA.2019.v13.i01.p0 6 [In Bahasa Indonesia]

[7] F.J. Taiwo, O.O. Feyisara, Understanding the Concept of Carrying capacity and its Relevance to Urban and Regional Planning, Journal of Environmental Studies 3(1) (2017) 1-5. 
[8] S.A. Santos, H.P.O. de Lima, S.M.F.S. Massruh, U.G. Abreu, W.M. Tom, S.M. Salis, E.L. Cardoso, D. de Oliveira, M.T.S. Soares, A. Onio, D.E. Santos, O. Luiz, F. de Oliveira, F. Calheiros, S.M.A. Crispim, M.A. Soriano, C.O.G. Am, A.P. Nunes, A. Luiz, and L.A. Pellegrin, A fuzzy logic-based tool to assess beef cattle ranching sustainability in complex environmental systems, Journal of Environmental Management (198) (2017) 95106.

DOI: https://doi.org/10.1016/j.jenvman.2017.04.076.

[9] A. Agus, T.S.M. Widi, Current situation and future prospects for beef cattle production in Indonesia - A review, Asian-Australas, Journal Animmal of Science 31(7) (2018) 976-983. DOI: https://doi.org/10.5713/ajas.18.0233

[10] L.V. Rasmussen, R. Bierbaum, J.A. Oldekop, A. Agrawal, Bridging the practitioner-researcher divide: Indicators to track environmental, economic, and sociocultural sustainability of agricultural commodity production, Global Environmental Change 42 (2017) 33-46. DOI: https://doi.org/10.1016/j.gloenvcha.2016.12.001

[11] E. Ashari, E. Juarini, Sumanto, S. Wibowo, Pedoman Analisis Potensi Wilayah Penyebaran dan Pengembangan Peternakan, Balai Penelitian Ternak dan Direktorat Bina Penyebaran dan Pengembangan Peternakan, Jakarta, 1995. [In Bahasa Indonesia]

[12] D. Sumarjono, Sumarsono, Sutiyono, Penerapan Analisis Jalur untuk Pengembangan Sapi Potong Berbasis Potensi Lahan Usahatani di Kabupaten Blora, Jawa Tengah, J. Indon. Trop. Anim. Agric. 33(3) (2008) 231-237. [In Bahasa Indonesia]

[13] Badan Pusat Statistik Kabupaten Gorontalo, Kabupaten Gorontalo dalam Angka 2020, CV Rivaldi, Jakarta, 2020. [In Bahasa Indonesia]

[14] M.F. Wiyatna, Potensi dan Strategi Pengembangan Sapi Potong di Kabupaten Sumedang Propinsi Jawa Barat, Tesis, Program Pascasarjana. Institut Pertanian Bogor, Bogor, 2002. [In Bahasa Indonesia]
[15] Sumanto, E. Juarini, Pedoman Identifikasi Potensi Wilayah dan Implementasi, Kerjasama Bagrpo Pembinaan Pengembangan Peternakan Pusat dan Balitnak Bogor, Bogor, 2004. [In Bahasa Indonesia]

[16] S.M. Mukson, P.I. Sari, H. Setiyawan, Faktorfaktor yang Mempengaruhi Potensi Pengembangan Ternak Sapi Potong Rakyat di Kecamatan Kaliori, Kabupaten Rembang, Jawa Tengah, J. Indon. Trop. Anim. Agric. 33(4) (2008) 305-312. [In Bahasa Indonesia]

[17] R.A.B. Talib, Keragaan Produksi Sapi Timor di Kabupaten Kupang, Nusa Tenggara Timur, Fakultas Peternakan Universitas Nusa Cendana Kupang, Kupang, 2008.

[18] R. Widiati, K.A. Santosa, S. Widodo, M. Masyhuri, Optimalisasi alokasi sumberdaya rumahtangga tani melalui integrasi usahatani tanaman dan sapi potong di Gunung Kidul Yogyakarta, Agro Ekonomi 9(2) (2002) 65-79. DOI:

https://doi.org/10.22146/agroekonomi.16797 [In Bahasa Indonesia]

[19] Nasrullah, B. Tappa, S. Said, E.M. Kaiin, Ketersediaan Pakan Ternak Ruminansia di Kalimantan Selatan, Makalah disampaikan pada Seminar Sehari dalam rangka Bulan Bakti Peternakan dan Kesehatan Hewan, Banjarbaru, 16 September 2004. [In Bahasa Indonesia] 